IRSTI 03.29.00

\author{
Kassymova D.B. \\ c.h.s. assistant professor, KIMEP university, \\ Kazakhstan, Almaty, e-mail: didar@kimep.kz

\section{TURKS-MESKHETIANS OF KAZAKHSTAN: GEOPOLITICAL CONTEXT OF REPATRIATION OPTIONS}

Turks-Meskhetians refer to a transnational ethnic group whose identity was formed as result of the group's accommodation practices to the changing external environments necessitated by the critical conditions of survival strategies development and adherence to identities prescribed by external regimes within the frameworks of limited choice. Internal political -administrative imperatives dictated by external geopolitical strategies conditioned the names of territorial units and ethnic groups living there. The Turks Meskhetians have been involved in lengthy, and so far unsuccessful debate on their right of return to their historical homelands, rather than dealing with healings of collective traumas. The paper is aimed to create an integrative scheme of the role of interplay of international, national and ethnic in-grouprelated factors in repatriation and integration decisions' making process.

Key words: Turks- Meskhetians, repatriation, civic identity.

\author{
Касымова А.Б. \\ т.Ғ.К, профессор-ассистент, ҚМЭБУ, \\ Қазақстан, Алматы қ., е-mail: didar@kimep.kz

\section{Қазақстандық түрік-месхетиндіктер: геосаяси контекстегі репатриация нұсқалары}

Түрік-месхетиндіктер трансұлттық этникалық топқа жатады, олардың бірегейлік қалыптасу жолы сындарлы кезеңдерде өзгермелі өмір сүру жағдайымен таңдау шектеулеріне бейімделудегі тәжірибеден өтті. Геосаяси стратегияның жемісі және ішкі саяси-әкімшілік нұсқаулықтар, олардың қазіргі өмір сүру орны мен ортасын айшықтап берді. Түрік-месхетиндіктер тарихи туған жеріне оралу үлерісінде ұзақ, таласты тосқауылдарға жолықты, бірегейлік, жадылық, мәселедегі зардап нәтижесінде, ұжымдық тарихи түсінікке жеткілікті тұжырымдама бере алмай отыр. Мақалада репатрианттарды қабылдаған қоғамның интеграциясы және халықаралық, ұлттық, және этникалық факторлардың осы мәселедегі интегративті орнын көрсетуді назарға а^ды.

Түйін сөздер: түрік-месхетиндіктер, репатриация, азаматтық бірегейлік.

\author{
Касымова А.Б. \\ к.и.н, ассистант-профессор, Университет КИМЭП, \\ Казахстан, г. Алматы, e-mail: didar@kimep.kz \\ Турки-месхетинцы Казахстана: \\ геополитический контекст вариантов репатриации
}

Турки-месхетинцы относятся к транснациональной этнической группе, их идентичность сформировалась в результате практик приспособления к меняющимся внешним условиям и приписываемым идентичностям в условиях критической необходимости выживания и ограниченного выбора. Внутренние политико-административные императивы, продиктованные геополитическими стратегиями, определяют и места их нынешнего проживания. Туркимесхетинцы вовлечены в Алительный и пока безуспешный спор по поводу права на возвращение на свою историческую родину, что во многом препятствует аАекватной формулировке проблемы 
комлективной исторической травмы, памяти и идентичности. В статье ставится задача обрисовать интегративную схему роли международных, национальных и этнических фракторов в вопросах репатриации группы или интеграции в принимающие сообщества.

Ключевые слова: турки-месхетинцы, репатриация, гражданская идентичность.

\section{Introduction}

Turks-Meskhetians refer to a transnational ethnic group whose identity was formed as result of the group's accommodation practices to the changing external environments necessitated by the critical conditions of survival strategies development and adherence to identities prescribed by external regimes within the frameworks of limited choice. Turks Meskhetians in different countries had to adapt to regimes disinterested in its history and preferences which power to live under. Internal political -administrative imperatives dictated by external geopolitical strategies conditioned the names of territorial units and ethnic groups living there. External identification in Turks-Meskhetians integration problems is very important for adaptation and integration into the mainstream society (Bugai $\mathrm{N}$. et. al). Turks-Meskhetians in the post-soviet Kazakhstan make up less than $10 \%$, but the problems of their integration into the Kazakhstani society or immigration/repatriation highlight a number of geopolitical issues. On the one side, their immigration would not change ethno-demographic balance statistically, but indicate the perspectives of other ethnic groups' integration into the Kazakhstani society in the light of nation-state building processes, on the other. The article elucidates the external challenges for the Turks-Meskhetians of Kazakhstan in the conditions of new geopolitical order formation in Eurasia. Territorialization of Turks-Meskhetians repatriation to Georgia or immigration to any other country depends on a number of factors that determine the right of return:

1) Conflict between prescribed identity and selfidentification of the group

2) Defining the historical homeland as an ethnic territory and prescribed settlement

3) External and domestic geopolitics of the receiving states

The geopolitical aspects of the TurksMeskhetians repatriation/immigration concerns internal and external security of Russia and Georgia, and other interested parties. The versions of immigration/repatriation include the following countries: 1) ancestral land- former Georgian SSR, now Republic of Georgia, 2) historical legendary fatherland- Republic of Turkey, 3) imperial
motherland-Russian Federation, ex-soviet republicsKazakhstan, Azerbaijan, Ukraine, Kyrgyzstan, 5) symbolic motherland alternative - USA.

The Stalinist 1944 deportation of TurksMeskhetians from Georgia to Central Asia radically changed their fate. By the NKVD order 001176, 20 September 1944 Turks-Meskhetians were accused in «non-acceptance of the collective farms system», «violation of state border», «collaboration with enemies, engaged in smuggling and services to the Turkish intelligence, recruitment of espionage elements and creation of bandit groupings». Other charges implied maintenance of family links with the relatives living in borderland areas of Turkey. After the death of J. Stalin, they were denied to the right of return due to external geopolitical considerations - Turkey was a soviet adversary as NATO member - and the Georgian soviet officials' protests. After the Fergana 1989 pogroms the soviet leadership organized Turks resettlement and most of them were directed to Russian Federation, mainly to Nechernozemie (Osipov A.).

\section{Research methodology}

The paper is based on interdisciplinary approach -review of the historical conditions for the policies of states where Turks-Meskhetians reside and liberal paradigm of repatriation that stems from the seminal work of Hannah Arendt, that producing volumes works conceptualizing various cases of repatriation in the post II World War period. H. Arendt (Arendt H.).

\section{Defining Turks Meskhetians}

Turks Meskhetians are differently named in various countries as geopolitical cleavages historically shaped their settlements' geography (Aydindun A. 202 (a). One of the key problems to provide a reasonable solution to the territorial settlement and status of Turks in the countries of residence and where they intend to migrate, is to define them as a group from political and ethno cultural characteristics. Turks-Meskhetians refer to the group of disappearing peoples who are losing main ethnic identity markers due to life in civilizationally alien environment. Their language 
relates to one of eastern-Anatolian dialects of the Turkish language of Oguz sub-group of Turkic group of Altaic language family. Most of the Turks living in the post-soviet space are bilingual as they had to adapt to the dominant cultural conditions (Aydindun A. 202 (b).

From ethno cultural perspective the disputed trajectory is to place them among the Turkic peoples, but the historical origin is not clear whether to trace them from the Turkic tribes that settled down in the Caucasian regions since Turkic incursions, or from the Turkicized indigenous ethnic groups inhabiting the Meskheti region of Georgia, after the area was conquered by Ottoman Turkey. The Georgian part insists on external pressure upon the identity transformation of indigenous populace.

By the international law definition Turks Meskhetians status varies, they full citizens in the countries of residence in the former soviet republics (Kazakhstan, Azerbaijan, Kyrgyzstan, Ukraine,
Uzbekistan), but in some them they experienced of refugee status (Ukraine, Azerbaijan) after 1989 Fergana events, while in the Russian Federation they are denied statuses of refugees and to obtain citizenship. Those, who failed to legalize in Russia, fall within the category of stateless persons and apatrids (Gupta).

Turks Meskhetians can also be classified as transnational ethnic group due to the following criteria:

1) Historical homeland is disputed

2) they are living in several countries- Kazakhstan, Russia, Azerbaijan, Turkey, USA, Georgia, and some others

3) their status in recipient countries is not definite for legal and civic/ethnic identification criteria.

4) most of them are dissatisfied with their status and applied/opted for migration/repatriation

5) International agencies are charged with search of solution to their situation.

Table - Turks Meskhetians in the countries' context

\begin{tabular}{|c|c|c|c|c|}
\hline Country & Number & Civic status & Names & Status conditional or not \\
\hline Azerbaijan & 80 thous. & $\begin{array}{l}70 \% \text { citizens of } \\
\text { Azerbaijan }\end{array}$ & $\begin{array}{l}\text { Turks Meskhetians/ Azeris/ } \\
\text { Akhalzih Turks }\end{array}$ & unconditional \\
\hline Kazakhstan & About 150,000 & $100 \%$ citizens & $\begin{array}{l}\text { Turks Meskhetians or Turks } \\
\text { Ahiska }\end{array}$ & unconditional \\
\hline Uzbekistan & $\begin{array}{l}\text { over } 20,000 \text { by unofficial } \\
\text { data, } 10 \text { thous by } 2000 \text { data }\end{array}$ & citizens & Turks Meskhetians & unconditional \\
\hline Kyrgyzstan & About 50 thous. & citizens & $\begin{array}{l}\text { Turks Meskhetians or Turks } \\
\text { Ahiska }\end{array}$ & unconditional \\
\hline Russian Federation & over 90 thous. & Mostly non-citizens & $\begin{array}{l}\text { Turks Meskhetians or Turks } \\
\text { Ahiska }\end{array}$ & conditional \\
\hline Ukraine & \begin{tabular}{|l|} 
Over 9.000 as of 2001. In \\
December 2015 Turkey \\
initiated migration of 3000 \\
Turks Meskhetians from \\
Slavyansk to Erzinjan, Turkey
\end{tabular} & citizens & Turks Meskhetians & unconditional \\
\hline Turkey & $40-50$ thous. & Citizens & Turks Ahiska & unconditional \\
\hline USA & about 12 thous. & Citizens, refugees & Turks Ahiska & unconditional \\
\hline Georgia & about 1 thous. & & $\begin{array}{l}\text { Meskhi/Muslims-Meskhi/ } \\
\text { Muslim Georgians / } \\
\text { deported Meskhi/Meskhi } \\
\text { repatriates/ deported from } \\
\text { Meskhetia population }\end{array}$ & Conditional \\
\hline
\end{tabular}

Source: https://www.kavkaz-uzel.eu/articles/165919/

'Finding Durable Solutions for the Meskhetians'. A Presentation of Preliminary Findings and a Roundtable Discussion With Government and Civil Society Actors in Georgia. Report on the Joint Conference organized by the ECMI and the State Minister of Georgia on Conflict Resolution Issues. By Denika Blacklock. Tbilisi, Georgia, 6 June 2005. ECMI Report \# 56. August 2005 


\section{The countries contexts}

Russian Federation The Turks Meskhetians became part of the Russian multiethnic society since late 1980s, when after the Fergana 1989 tragic events the soviet leadership resettled them in Nechernozem'e, and after 1991, many Turks moved to the southern areas with more favorable climatic conditions and economic opportunities. But the regional authorities disinterested in the Muslim population growth in the security sensitive areas close to the Caucasus do not provide conditions for Turks accommodation and legalization. Everyday nationalism has become a serious threat to the very existence of the group and leads to gradual erosion of their identity, as they are denied the right for civic status (citizenship, official registration/propiska, access to social resources as medicine and education) and maintenance of ethnic practices (rites, religion and language) and ethnic communication space is shrinking (Ahmetieva et al.).

The plans of the regional authorities to arrange Turks resettlement to labor deficient regions failed, as the Turks are not willing to move there (Mamayev). By 2018 Turks have been residing in the Kuban and Stavropol'sky kray mostly. Against the law of the Russian Federation «On national-cultural autonomy» (1996), the Turks Meskhetians living in the compact way in some Russian regions are denied that autonomous unit creation, being not native dwellers, but newcomers (Koriouchkina).

The only legal document regulating their settlement right on the territory of the Russian Federation is the law «On rehabilitation of the repressed peoples». Inter-ministerial commission for solution to the Turks Meskhetians' problems residing on the territory of the Russian Federation set up by the special decree of the government of the Russian Federation № 1129-r as of 18 July 1994, failed and was dissolved, while all the issues relating the Turks Meskhetians were delegated to the governmental commission on migration policy that ceased its activities soon as well: «Activities and declarations of the commission, its composition and its working document dated of September 1998 indicate that the government viewed the problems of Turks Meskhetians exclusively as the security problem and of the international relations, not as that of social integration or ethnic minority rights protection within the country» (Yunussov). Meskhetian Turks were listed in the Russian Federation among 10 totally deported ethnic groups, but not listed among those to be rehabilitated. They should claim that individually, but under the
Russian legislation they must be first rehabilitated by the governments of Georgia, or where they used to live before they came to Russia- Uzbekistan, Kazakhstan, Kyrgyzstan.

The Turks Meskhetians status in post-1991 Russia depends to great extent on how regime of citizenship ifs interpreted at the local levels by the regional administrations who have some relative freedom in interpretation and implementation of some legal acts in accordance with the statusquo preservation strategy-securitization due to prevalence of conflict potential over commitment to international and national norms. One of the major problems in relations between the Turks Meskhetians and the local populace in the south of Russia is Qazaks. Osipov considers, that Kuban authorities are aimed to instigate clashes between Turks and Qazaks and in that way to channel the problem of civic rights granting to Turks to the interethnic conflicts trajectory and prove the incompatibility of co-existence between the civilizationally alien ethnic groups. But in reality it would camouflage legalization of land seizure by the geopolitical heirs of the Caucasus conquest (Qazaks), but not granting the living space to the newcomers (Kuchins). Russia is interested in cleansing the southern areas adjacent to the North Caucasus from Muslim groups. Thus, Turks Meskhetians problem is securitized in the Russian Federation in the light of the Caucasian Emirate creation plans (Kramer). The Russian intelligence also express concerns that Turks adherence to destructive Islamic movements - Wahhabism, Salafism and Pan-Turkism- would destabilize the social-political situation and territorial integrity of the country. These movements of pro-Turkish orientation rooted in some areas with predominant Turkish populace, as a case it is Nurcilar, an affiliate of the Gulen network. Behind the declared educational objectives for the Turkish communities it hides an agenda to spread the Turkish political influence (official and nonofficial), and promote among them the motherland concept of extended Turkey (Ordynsky). The Russian government is afraid of the perspective to turn into the country of migrants, most of who, are Muslims. Citizenship regime is applied not unilaterally but in relation of some ethnic groups/ individuals to state. In etatist terms- interests of state prevail, but state officials have also power and freedom to formulate rationale for giving or not citizenship. Citizenship regime is closely connected with political imagination that excludes or includes people of certain group as members of state. The reasons of the Russian provincial administrations 
denial of citizenship- Turks might claim afterwards by the Russian constitution cultural autonomy. Repatriation to Russia, therefore is problematic for Turks due to the following reasons: although Turks may come and settle in some areas in southern Russian provinces, as they have relatives living there and free non-visa regime between former soviet states, but their further legalization status is blocked by non-visa stay, residence permits and procedures of citizenship application. The Russian authorities' position in provincial areas bordering or those categorized as securitized. Promotion of the Turks Meskhetians' image as the «other» has been part of general xenophobia and Islamophobia. The Turks Meskhetians are portrayed by the Russian security bodies as potential bearers and followers of extremist forms of Islamism, exported and backed by the Turkish political circles closely affiliated with the USA, and CIA, in particular. Such position of the Russian authorities does not fall within the general course and politics of repatriation of all ethnic groups known as "Compatriots» that embraces all former soviet citizens. However, the Turks Meskhetians could apply for the status of «compatriots», but in that case they would have to be dispatched for living in the designed by the Russian migration authorities' provinces. Thus, Russian rationale for denial of citizenship for Turks Meskhetians falls into the following baskets:

1) Russia took over the status of the former USSR regarding its UN Security Council seat and nuclear status, as well as some other obligations, but not obligation towards its former citizens, most of whom were victims of the soviet policies and Gorbachev politics.

2) Russian government disregards its commitment on many international agreements concerning the rights of displaced and stateless people.

3) Russia accepted and provided conditions for citizenship to many refugees, from conflict zones of former USSR, but on selective approach.

4) Russia scares compact concentration of Turks Meskhetians in some sensitive prone to ethnic conflict areas.

5) Turks Meskhetians are viewed as potentially corrupted by their greater historical homeland and patron- Turkey.

Turkey's context The government of Turkey views Turks Meskhetians as potential repatriates to their historical homeland. Foreign Ministry of Turkey annually makes statements on forced deportation of Turks Ahiska form the Caucasus. On 2 July 1992 the Supreme national Assembly of Turkey radopted the Law №3835 «On immigration and settlement of Turks-Meskhetians», that legally guaranteed their immigration in their own way and by annual immigration quotas. The law envisions creation of commissions to elaborate measure to provide employment, temporal settlements and relief from all fees and taxes. Turkey set up a negotiation link with Georgia for creation of repatriation mechanism for Turks Meskhetians (Aydingun, 2002a). In November 2017, Turkey announced decision to give citizenship to 23.000 Turk Meskhetians (Turkey).

American context The international organizations were seriously concerned with the humans and ethnic minorities' rights violation in the southern regions of Russia, and in 2000 the International Organization for Migration arranged the immigration to the USA of several thousands of Turkish families. Out of 21 thous. applications, the USA granted the Turks Meskhetians the right of legal status, to become US citizens (Aydigun, Harding), as «special humanitarian concerns, on the grounds of their discrimination and statelessness (Koriouchkina). But in the USA, the Turks despite the efforts undertaken by their communities' leaders, represent the groups of immigrants from the former USSR or included into the vast Turkish diaspora (Pirtskhalava). They would strive to incorporate into the niches offered by the American regimes, that differ from state to state due to the population composition, through adoption of the American life style and would become part of the «melting pot» with dominant Euro-American culture - language, mindset, accept norms and forms of inter-cultural social communication, maintaining religious and ethnic practices within the framework of narrow community (Omer). Cultural differences and political orientations also differ among groups of Turks in the USA could be on one side, criteria for inclusion, but lead to some kind of dimensional alienation. For Turks from Turkey, historical homeland is Turkey, while for Turks Meskhetians it is part of modern day Georgia. The same relates to political and religious sympathies. The Turks Meskhetians from former USSR, irrespective their origin, are less religious, and their language and cultural practices being filtered by the communist ideology contain cultural elements of soviet period and multiethnic ethnic environment of the countries of origin. Political symbolism of imagined belonging to external countries also differs. For Turks from Turkey they refer to the flag of Turkey, country image, its achievements, etc. But what is political symbolism for Turks Meskhetians? Historical episodes of their deportations would erode being part of the common memory of the migrants from the former USSR. 
The Azerbaijani realities In 1958 a small group of Turks arrived to Azerbaijan, and for the period 1950-1960s came about 50 thous., and after the Fergana events - over 40 thous. (Gadjiev). The Turks Meskhetians (named as Akhalzih Turks) obtained the Azerbaijani citizenship as refugees automatically as Republic of Azerbaijan joined the UN convention on refugees status of 1951, the 1967 Protocol to the convention, the Geneva Convention of 1949, and some other international legal documents (Yunussov, $b$ ).

Context of Georgia In the soviet times, the Georgian leadership rejected the right of return to Turks-Meskhetians. In the post-1991 period, nationalist rhetoric and politics also dominated in the discourse state-nation building processes: «Georgian is not for Muslims». Only after the entry the Council of Europe (1999), the Georgian authorities had to deal with the Meskhetians' return program, that at the same time became an integral part of general democratization program (human and ethnic minorities' rights observance, supremacy of law and democratic reforms) (Tarkhan-Mouravi). But it took eight years for the Georgian regimes to adopt a Repatriation law that does not clearly define the repatriation, potential repatriates' rights and commitments of the country on their acceptance and settlement. Only in 2011, after the Council of Europe criticized the Georgia's politics, Tbilisi launched a formal process to grant repatriate status to Turks- Meskhetians (Yemelyanova). The Parliamentary Assembly of the Council of Europe- identifies Turks as stateless, and designates their homeland where they by free choice should be repatriated as Georgia (as they were deported from this particular place in what is now part of Georgia) (Parliamentary Assembly). Georgiaon27th of April 1999 the Council of Europe entitled Georgia to start repatriation process within 12 years. The government of Georgia set up a commission to work out legal basis on repatriation of Meskhetian Turks. In March 1999, in Vienna was held an international meeting on repatriation issues and the Georgian government took upon commitments: those Turks Meskhetians living in Georgia by the end of 1999 would obtain citizenship. On 28th of June 1999, Georgia joined 1951 UN Convention of refugee status. But did not ratify Convention on End of statelessness that directly refers to Turks Meskhetians. But new problems were looming on the way: under the European Charter on Human Rights, repatriates have the right of free choice to live in any part of the country by their choice. But the Georgian government protests against that right.
The law on repatriation of persons that were in forced way deported by the USSR from Georgian SSR in 1940s was adopted only on 11 July 2007 , and entered into force on 1 January 2008. It established the deadline for applications submission for repatriate status as January 1, 2009 (Sumbadze et al). The Law on repatriation allowed Turks Meskhetians to return to their homeland, but return was conditional - an applicant was to collect 11 various documents to prove that he/she was a descendant of deported persons. Moreover, upon obtaining the repatriate status an applicant was to give up his/her former citizenship, come to Georgia and await the decision on Georgian citizenship granting. The program was in force from 1 January 2008 to 1 January 2010. Over 5000 applications were submitted to consulates of Georgia in different countries. But after 1 January 2010, Georgia did not accept any applications (Yemelyanova).

The law of Georgia of 2007 that came in to force on 1 January 2008 «On repatriation of persons that were in forced way deported by the USSR from Georgian SSR in 1940s», grounds legal conditions for repatriation system on the basis of historical justice restoration, principles of voluntary and stage-by-stage return. The law defines repatriate as «forcefully deported person»-person that in 1940-s was forcefully deported based on the decree №6279 of the State Committee of Defense, dated 31 July 1944 from the Georgian SSR to other soviet republics. «Repatriate status seeker» is defined as a legally registered person as repatriate status seeker; «repatriate» is a person who was granted repatriate status in due legal way. Applications were under separate review since 1 January 2009, but the principle of family unity was observed. In the applications' review process, the priority was given to the Georgian language competence. Repatriate status provided an opportunity to get the Georgian citizenship in line with the order under article 271 of organic law of Georgia «On citizenship of Georgia». A person granted repatriate status had in 6-month period after repatriate status granting to submit to the Ministry for refugees and settlement a document certifying that he/she was not citizen of the country where he/ she lived before the repatriate status was granted (Yemelyanova). The Georgian side discriminates between the descendants of deported Meskhetians into two groups - those who identify themselves as Turks Muslims and Meskhis with Georgian roots. The politics of Georgia on Turks Meskhetians' repatriation is determined by a number of factors of nation/state building model and European geopolitical orientation. Georgia aims to join the European 
integration processes via membership in the Council of Europe and further on, in the European Union and NATO. Domestic politics, on one side, envisions creation of conditions to prevent ethnic conflicts, and on the other side, handle external borders challenges risks, in Meskhetia, in particular. Loss of Abkhazia and Southern Ossetia, economically active zones were detrimental for domestic social situation (refugees, economic crimes rate, unemployment, etc.) and securitized perception of ethnically diverse regions of the country by the Georgian leadership.

Domestic geopolitical consideration influence the decision of the Georgian government to avoid interethnic clashes between ethnic groups living in Meskhetia (Georgians and Armenians) and incoming Turks (Gruzia). Therefore, repatriation settlement plan envisions arrival only of families with Georgian roots. Moreover, Samtze Javahetia (includes Meskhetia and Javahetia) borders several states- Turkey, Iran and Armenia. Pan-Turkic plans of Turkey alarm both Russia and Georgia. Oil pipeline Baku-Tbilisi-Ceyhan runs across the territory, and that necessitates security guarantees for all interested parties. The Georgian leadership is concerned with the perspective of the Muslim enclave emergence in the area of Turkish strategic interests (Yegorov). Historical-cultural aspect of the Georgia's unwillingness to solve the Turks-Meskhetians repatriation proceeds from interpretation of historical rights of some ethic groups on those lands. The Georgian authorities and historians employ primordialist arguments to construct a discourse on original inhabitants that further on were bearers of Georgian statehood in within historical evolution. Some Georgian experts consider that the ethnic consciousness of Meskhi is greatly mythologized by the legend on their Turkish origin. Therefore, any religious and linguistic arguments are rejected on grounds that population (part of it) had to convert to a new faith and adopt new language under the threat of power and force. The Georgian etyhnonationalist discourse discourages the Turks Meskhetians living abroad, as its recognition would imply change of ethno-religious identity- to quite being Muslims and Turks. Whatever is Georgian is ours must be selfidentification of the Turks, and serve as a key factor for their return, granting them legal guarantees and formation of favorable conditions to integrate into the recipient community and larger Georgian society (Sumbadze et al.). Georgia declared on the dominance of Kartvel roots of Meskhetians as a key criteria for repatriation and further integration into the Georgian society. One of the administrative requirements of the Georgian administrative bodies to already returned Turks to accept external markers of new status and civic identity that would lead to change of ethnic markers- adoption of Georgian family names personal names, self -identification as Georgians and socialization by Georgian canals, including education in the Georgian language (Eurasianet). The Georgian experts consider that ethnic name Turks Meskhetians does not correspond the historical reality as the major group living in Meskhetia (viewed a cradle of the Georgian culture) was a sub ethnic groups of Meskhi. External factors - Ottoman Empire control establishment over part of Georgia and further islamization of the population led to creation of a cultural orientation to Turkey and new identity formation based on Islam as a survival strategy while primordialist foundations of identity, did not corrupt being dependent on natural-climatic conditions and genetic roots. Georgia's annexation by the Russian Empire resulted in further turkicization of the population of Meskhetia but with the Russian emphasis. The Russian empire implemented the projects on new identity formation in the Caucasus out of Azeris, Kurds and Muslims of Meskhetia (Mamulia). In Meskhetia and Javahetia, Russia promoted Armenization to create a Christian enclave (Chervonnaya). The academia of Georgia does not want to recognize Turks Meskhetians under their name as Turks Meskhetians, but as Meskhi or Muslim Georgians as indigenous population of Georgia, that would pave down the claims on specials rights within these lands for Turks, who strongly believe that their ancestral lands stretches beyond the borders to present-day territory of Turkey. And that would provide also grounds for extraterritorial identity of Turks, on one side, and further claims of Turkey proper.

The Kazakhstani context Three generations of Turks Meskhetians have been living in Kazakhstan. The data on Turks Meskhetians living in Kazakhstan differ. By 1989 census they numbered 78 thous, while by the official statistics as of 2018 they number about 105 thous. (Census of 2009). The data of the Turkish leaders is close to $180.000-200.000$, that is explained that many Turks were registered as Azeri since soviet times and many of them did not change their official identity. Linguistic situation of Turks, among them are Turks Ahiska, Khemshils and Lazes, in Kazakhstan is very critical as they use only colloquial Turkish, the written version is obsolete as it refers to the old Turkish practiced before the Kemalist reforms in Turkey proper. Internally Turks in Kazakhstan are divided into yerli (Turkic speaking agrarians) and terekeme (shepherds with dominant Azeri component) (Rakisheva). 
For Turks of Kazakhstan the ethnic identity marker are Islam and language along the sympathy to Turkey, that in their opinion, became major reasons for their deportation from the territory of Georgia in late period of World War II. The Turks Meskhetians are closer to the most part of the population of Kazakhstan due to the proximity of several civilization parameters - religion, Turkic culture, everyday Islamic practices and linguistic commonality (Savin). Turks Meskhetian community at all levels of interactions with the Kazakhstani authorities demonstrate their loyalty to the regime and adherence to the state initiated programs on the Kazakhstani identity formation and state/nation building. The Kazakhstani context provides the most favorable conditions for the Turks ethnic cultural preservation and opportunities for civic and political development. From the gratitude letter of Turks-Meskhetians to the President of the Republic of Kazakhstan N.A. Nazarbayev: «The history brought us together on the native land of Kazakhs, where due to your politics and introduced concept of tolerance we shoulder to shoulder with other ethnic groups. Let us express our endless appreciation, deep respect and clean-hearted gratitude to You- First president of the country, where peacefully are living and developing various ethnic groups. We express our gratitude for all you made for peace preservations and stability maintenance in our country, for the opportunities you gave to us as for the citizens of Kazakhstan with equal opportunities. We, from our side, commit ourselves to do upmost for economic development, prosperity, and welfare of Kazakhstan channel all our forces for friendship preservation, contribute to the strengthening of links between Kazakhstan and other countries.»(Blagodarstvennoe pis'mo). But, the Turks of Kazakhstan see the vector of repatriation as Turkey that in the external world represent the interests of ethnic Turks.

\section{Conclusion}

One of the unsettled problems for all researchers in the field of ethnic groups without states/outside the nation-states, is to explain why these groups are not wanted in the recipient societies in some countries. The Turks Meskhetinas problems of territorialization to great extent depends on the policies of the states that would provide them settlement and legal grounds for ethnic group survival, but the ethnocultural identity would be maintained only within some countries- Turkey and Kazakhstan.

\section{References}

Akhmetieva V., Karastelev V., Yudina N. Zhizn' bez prav. Polozhenie ahiska turok na yuge Rossii v 2016 gody. COBA: Information-analytical center. Moscow Helsinki group.

Arendt H. (1967). The Origins of Totalitarianism, 2nd ed. London.

Aydingun, A. (2002a). Ahiska (Meskhetian) Turks: Source of conflict in the Caucasus? The International Journal of Human Rights, 6 (2). 49-64.

Aydingun, A. (2002b). Creating, recreating and redefining ethnic identity: Ahiska/Meskhetian Turks in Soviet and post-Soviet contexts. Central Asian Survey, 21(2). 185-197.

Kuznetsov, and Steve Swerdlow (2006). Meskhetian Turks. An Introduction to their History, Culture and Resettlement Experiences. Culture Profile No. 20. September. Center for Applied Linguistics. URL: http://www.cal.org/CO/pdffiles/mturks.pdf (Date $1-5,09.2018)$.

Blagodarstvennoye pis'mo Prezidenty Respubliki Kazakhstan Nursultany Abishevichy Nazarbayevy ot turok meskhetnitsev // http://www.ahiska-gazeta.com/ru/pages/315.html (Date 1-5, 09. 2018).

Bugai N. Mamayev M. (2015). Mezhdunarodnoye obschestvennoe ob’edinenie turok-meskhetintsev «Vatan» kak institute vlasti grazhdanskogo obschetva // Historical and social educational ideas. Tom 7 \#8. pp. 22-28.

Chervonnaya S. Problemy repatriatsii turok-meskhetintsev. K otchety delegatsii FSNE o poezdke v Gruziu i Rossiu 8-13 noyabrya 1998 goda, razdel «Pozitsia armyanskoi diaspory i ofitsialnogo Yerevana». Eurasianet.org 25 Mar. 2003; RFA/RL 15 Aug. (Date 1-5, 09. 2018).

Gadjiev A. Akhalzihskie turki. Istoria, etnografia, folclor. URL: //http: www. academia.edu (Date 1-5, 09. 2018).

Gruzia, Samtshe-Javahetia I turkskoye kol'tso vokrug Armenii //URL: https://regnum.ru/news/202173.html (Date 1-5, 09. 2018).

Gupta P. (2016). Krasnodarsky krai Rossiskoi Federatsii: turki - meskhetintsy - facticheskie apatridy//Tsentralnaya Aziya i Kavkaz. \# 5 (47). Pp. 145-159.

Koriouchkina L. (2009). Meskhetian Turks and the regime of citizenship in Russia. Ethnology. Vol. 48, no. 1. Winter. pp. $39-52$.

Kramer M. (208). «Prospects for Islamic Radicalism and Violent Extremism in the North Caucasus and Central Asia, «PONARS Eurasia Memo No. 28. 
Kuchins Andrew C., Mathew Malarkey and Sergey Markedonov, The North Caucasus: Russia's Volatile Frontier (Center for Strategic and International Studies, 2011). March Report, 13.

Mamayev M. (2010). Turki-meskhetintsy v etnopoliticheskoi sityatsii Severnogo Kavkaza: vykhod iz krizisnogo sostoyania// Izvestiya Samarskogo nauchnogo tsentra Rossiskoi akademii nauk. V. 12, № 2. p. 285-289.

Mamulia G. (1999) Kontseptsiya gosudarstvennoi politiki Gruzii v ontoshenii deprotirovannukh i repatriirovannykh narodov // Tsentralnaya Azia i Kavkaz. №1(2).

Omer Avci, Understanding the Culture of Ahiska Turks in Wheaton, Illinois: A Case Study. The Qualitative Report 2012 Volume 17, Article 87, 1-23. URL: // http://www.nova.edu/ssss/QR/QR17/avci.pdf (Date 1-5, 09. 2018).

Ordynsky V. Turki meskhetintsy v Rossii: mezhdy pan-turkizmom i wahhabizmom. // http://www.kavkazoved.info/ news/2012/02/10/turki-meshetincy-mezhdu-pantjurkizmom-i-vahhabizmom-i.html (Date 1-5, 09. 2018).

Osipov A. «Ferganskie sobutia»: dvadtsat let spustya. Istoria bez uroka. // URL: http://www.fergananews.com/articles/6197 (Date 1-5, 09. 2018).

Parliamentary Assembly. Doc 10451, 4 February 2005. The situation of the deported Meskhetian population. Report. Committee on Migration, Refugees and Population.

Pirtskhalava E. (2015). Surmanidze L., Identity Strategies of Muslim Meskhetians (Meskhetian Turks) in Cultural Context// Cultural and Religious Studies, Mar.-Apr. Vol. 3, No. 2. pp. 99-105.

Rakisheva B., Mazhitova A. Turkskaya osnova aka factor adaptatsii: na primere turkov-meskhetinsev, prozhivauschih v Kazakhstane i Kazakhskoi diaspory Stambula. Journal of Azerbaijani Studies. 369-378. URL: // http://jhss-khazar.org/wp-content/ uploads/2010/06/29.pdf (Date 1-5, 09. 2018).

Savin I. (2007). Successful integration but inadequate protection: the Meskhetian Turks in Kazakhstan. In Trier \&A.Khanzhin (Eds), Meskhetian Turks at a crossroads: Integration, repatriation or resettlement? Berlin, Germany: Lit Verlag, pp. 43-79.

Sumbadze N., Tarkhan-Mouravi G. Repatriation and adaptation of Deported Meskhetians: Society and state in supra-national context. URL: http://www.policy.hu/sumbadze/osiipf.html

Tarkhan-Mouravi (2007). G. Legal and Political Aspects of the Issue of Muslim Meskhetians (Meskhetian Turks), in Trier, T. and A.Khanzhin (eds). The Meskhetian Turks at a Crossroads: Integration, repatriation or Resettlement, London. Transactions Publishers. P. 493.

Turkey to give citizenship to 23,000 Ahiska Turks. URL://https://www.dailysabah.com/minorities/2017/11/05/turkey-to-givecitizenship-to-23000-ahiska-turks Yegorov A. Problema turkov -meskhetintsev v zalozhnikah geopolitiki //URL: http://www.kavkazoved.info/news/2011/08/28/problema-turok-meshetincev-v-zalozhnikah-geopolitiki.html (Date 1-5, 09. 2018).

Yemelyanova G. (2015). Georgia's European Quest: The Challenge of the Meskhetian Turks. //Caucasus International. Vol. 5. No: 3. Winter. P. 77-87.

Yunussov A. (a)Ahiskinskie (meskhetinskie) turki: dvazhdy deprotirovanny narod . ULR: // http://ca-c.org/journal/cac-021999/st 20 junusov.shtml (Date 1-5, 09. 2018).

Yunusov A. (2013). (b) Asylum Seekers, Refugees, and IDPs in Azerbaijan: Issues and Perspectives. CARIM-East Explanatory Note 13/125. September (Date 1-5, 09. 2018). 